\section{Defining and implementing a National Policy for Science, Technology, and Innovation in Health: lessons from the Brazilian experience}

\author{
Definição e implementação de uma Política \\ Nacional de Ciência, Tecnologia e Inovação \\ em Saúde: lições a partir da experiência brasileira
}

\author{
1 Fundação Oswaldo Cruz, \\ Rio de Janeiro, Brasil. \\ 2 Departamento de Nutrição, \\ Universidade de Brasília, \\ Brasília, Brasil. \\ 3 Departamento de Ciência \\ e Tecnologia, Ministério \\ da Saúde, Brasília, Brasil. \\ Correspondence \\ R. Guimarães \\ Fundação Oswaldo Cruz. \\ Av. Brasil 4365, Pavilhão \\ Mourisco, sala 111, \\ Rio de Janeiro, $R J$ \\ 21045-900, Brasil. \\ rfg@fiocruz.br
}

\begin{abstract}
The need for clearly-defined health research policies and priorities has been emphasized in the international scenario. In Brazil, this process began in 2003, when a group appointed by the National Health Council proposed 20 subagendas to account for the various health research specificities. The second step was to identify research priorities for each sub-agenda during national seminars involving 510 researchers and policymakers. The $2^{\text {nd }}$ National Conference on Science, Technology, and Innovation in Health was held in July 2004. During the preparatory phase, 307 cities and 24 States organized local conferences, involving 15,000 participants. Some 360 health sector delegates were appointed during the local conferences, in addition to those from the education and science and technology sectors. During the Conference, the national policy was approved and 3 other sub-agendas were introduced and approved. The national policy and the priority agenda are currently guiding investments by the Ministry of Health for research and development, and to a certain extent those from the Ministry of Science and Technology as well. From 2003 to 2005, 24 calls for proposals were launched; as a result, 3,962 research projects were submitted and 1,300 financed.
\end{abstract}

Research; Consumer Participation; Health Policy
Reinaldo Guimarães 1

Leonor Maria Pacheco Santos 2

Antonia Angulo-Tuesta ${ }^{3}$

Suzanne Jacob Serruya ${ }^{3}$

\section{Introduction}

United Nations Secretary-General Kofi Annan recently addressed the issue of Science for All Nations, highlighting that "no nation that wants to shape informed policies and take effective action ... can afford to be without its own independent capacity in S\&T", and "every nation should develop a $S \& T$ strategy that reflects local priorities" 1 (p. 925).

The need to establish health research policies and priorities at a global level has been emphasized, taking into account that the social and environmental contexts that determine disease are no longer national in scope, but increasingly global: health-determining phenomena transcend national borders and political jurisdictions 2 .

The Commission on Health Research for Development (CHRD), created in 1987, worked to determine the status and the factors constraining health and health research in non-industrialized countries. Many of the Commission's findings elaborate on the inequity theme, describing large disparities in how resources are distributed, research priorities are defined, and research capacities are strengthened (or neglected). Four mains actions were recommended: encourage countries to undertake essential national health research, address common health problems through international partnerships, mobilize larger and more sus- 
tained financial support, and establish an international mechanism to monitor progress and promote financial and technical support for research on health problems in developing countries. The Commission's 1990 report already identified the challenge to establish coherence in research responses to high-priority problems at the national and international levels: “...each developing country will need to set national priorities for research, for using both domestic and external resources...." 3 (p. 88-9).

A direct follow-up of the Commission's recommendations was the interim Task Force on Health Research for Development (TFHRD), established in 1991. With respect to setting priorities, the Task Force analyzed the problem as follows: "The mechanisms for identifying research priorities often fail to focus attention on the key issues affecting the health of the majority of the population, especially the needs of the most vulnerable and the disadvantaged" 4 ( $\mathrm{p}$. 24). Priorities are usually narrowly constructed along disciplinary lines and oriented chiefly towards medical technology. Each interested group - scientists, health policymakers, healthcare providers, and the population/patients had a different perspective on the issues needing most urgent attention. The policy setting process usually failed to effectively accommodate these differing views to achieve a consensus on goals and strategies for health research 4 .

Some tools and methodologies were developed for health research policy setting, like burden-of-disease analysis, the five-step process, combined-approach methodologies, etc. The importance of fairness and procedural justice in setting priorities is clear, and careful attention to consensus-building increases the likelihood of compliance and adds legitimacy to results. Despite some progress, the methodological debate on policy setting, particularly at the national level, is more open than ever 5,6.

Facilitated by the Council on Health Research for Development (COHRED), which replaced the TFHRD in 1993, an increasing number of developing countries started experimenting with and implementing health research policy setting 6 . Few experiences were reported in the international literature, and when so, as very short reports 7 .

However, in our opinion, equal consideration should be given not only to setting policies and establishing priorities, but also on how to implement them into actual programs and projects. The present article describes how this was accomplished in a middle-income country and in a relatively short period of time. While working in the Department of Science and Tech- nology (Departamento de Ciência e Tecnologia DECIT) in the Brazilian Ministry of Health, the authors designed and conducted the establishment of a National Policy for Science, Technology, and Innovation in Health and the Priority Agenda for Health Research. The article describes the policy's implementation and twoyear follow-up. It also reports in some detail on this innovative and participatory experience, which, although responding to the specificities of the Unified National Health System (Sistema Único de Saúde - SUS), could be reproduced in other settings, given adequate political will and financial support.

\section{Context of the Brazilian health system}

The health system was profoundly modified after the 1988 Brazilian Constitution, due to an extensive health reform based on proposals set forth during the 8th National Health Conference (1986). The basic principles guiding the SUS are: decentralization, comprehensive care (promotion, protection, early diagnosis, prevention, and rehabilitation), universal coverage, equity, and community participation.

Presently, three main health delivery systems coexist in the country: the SUS, which provides free care to all residents in the country (with a population of some 175 million), the Supplementary Health System (SHS) run by private healthcare insurance companies or health cooperatives (covering 35 million paying members), and the Private Health System (PHS), totally private, used only by the highest-income population. Some criticize that although "private", both the SHS and PHS receive government subsidies, because all incurrent costs can be claimed as personal income tax write-offs, thus diminishing state revenues 8 .

Unified National Health System (SUS) numbers are impressive: in 2003, it accounted for 268 million medical consultations, 83 million immunizations, and 12 million hospitalizations 9 . In many circumstances the higher-income population also relies on the SUS, especially in certain renowned public hospitals, emergency care, and some exceptionally efficient SUS programs like organ transplantation, AIDS care, and immunizations.

Funding for the SUS is guaranteed by Constitutional Amendment 29 10, approved in 2000, according to which Federal funds should increase at a rate of $5 \%$ a year and States and municipalities are obliged to spend $12 \%$ and $15 \%$ of their respective revenues on health. The amendment was instrumental for maintaining certain 
stability in Federal health expenditures, around $1.85 \%$ of the GDP from 2000 to 2003 . More importantly, it improved health investments by States and municipalities: in the period 20002003, during which time their average expenditures increased from $0.57 \%$ to $0.79 \%$ and from $0.67 \%$ to $0.91 \%$, respectively, of the GDP 11 .

In 2001, distribution of Federal health funds was: (1) $12.2 \%$ to municipalities for primary healthcare (PAB - allocation proportional to population size); (2) $40.6 \%$ to States and municipalities to fund secondary and tertiary healthcare (outpatient and hospital care); (3) $13.8 \%$ to municipalities for special public health programs (PAB variable); (4) $33.4 \%$ to pay private hospitals that deliver secondary and tertiary healthcare to SUS patients 9 . Unified National Health System (SUS) governance is shared at the three levels of government as illustrated schematically in Figure 1.

A landmark of SUS is community participation, guaranteed by a network of more than 5,000 Municipal Health Councils, 27 State Health Councils, and the National Health Council, involving some 100,000 individuals in this voluntary work. The four social sectors are represented in these councils: clientele or community representatives $(50 \%)$, health providers plus health managers (25\%), and healthcare workers $(25 \%)$. Most of the decisions on healthcare at the three governmental levels, such as budget, construction of health facilities, implementation of health programs, etc., must be approved by health councils 10 . The participatory process reaches its peak during the National Health Conferences: the latest, held in December 2003, involved approximately 300,000 people at three levels: municipal, State, and national. National Health Conferences are an integral part of the Brazilian health system because they play a central role in shaping the country's health policies. In addition to the 12 general conferences held so far, thematic conferences are also organized to deal with more specific issues, such as science and technology in health.

The Brazilian scientific community played a central role in designing the health reform and shaping the SUS. Implementation of the SUS depended greatly on popular demands and was a conquest of our politically-engaged public health scientists. We should mention here the late Sergio Arouca (1942-2003) as one of our finest examples of an extremely productive scientist and equally active politician. He chaired the seminal 8th National Health Conference in 1986 and was elected to the Brazilian National Congress shortly thereafter, where he spearheaded the approval of the health reform in the 1988 Constitution.
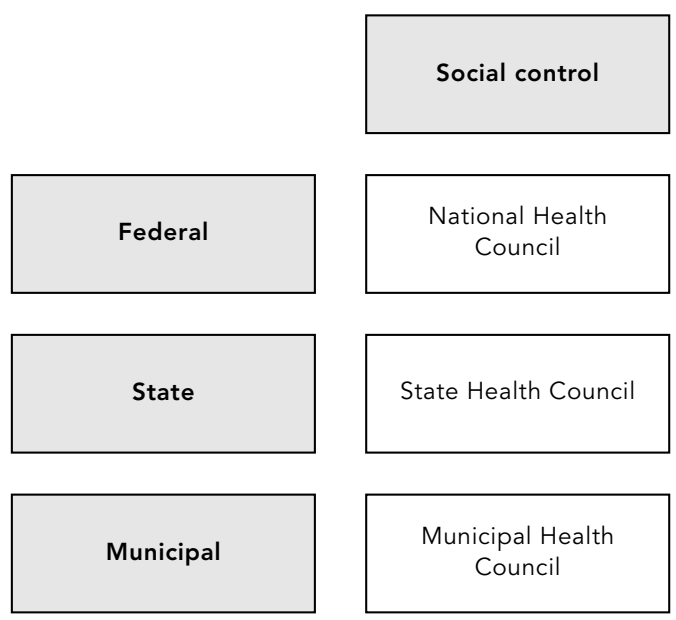

Municipal Secretariat of Health
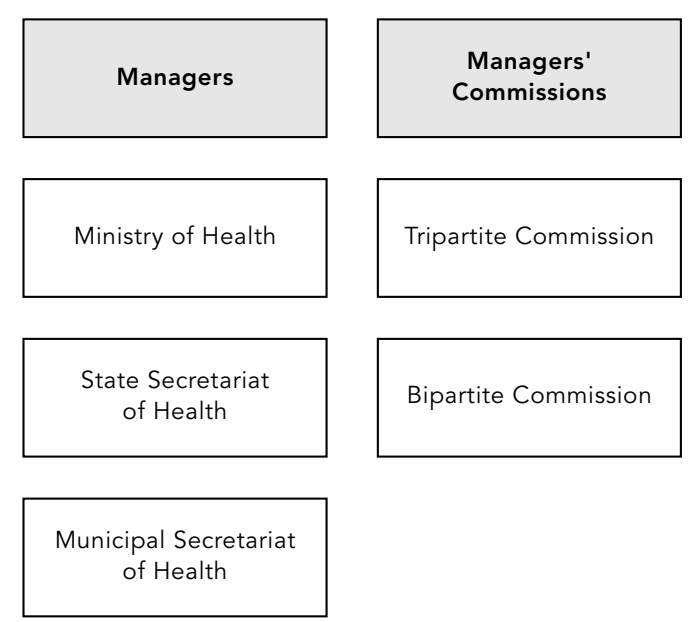
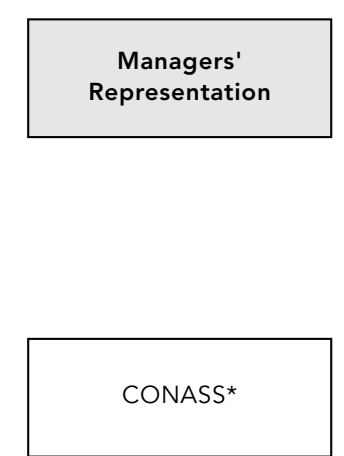

CONASEMS**

* National Council of State Health Secretaries;

** National Council of Municipal Health Secretaries;

Source: Noronha et al. 10. 


\section{An overview of health research in Brazil}

In 2004, 6,471 research groups were involved in health research in Brazil, with 25,562 researchers (15,978 of whom with PhDs), corresponding to about $30 \%$ of total research efforts in Brazil (Figure 2). These data were retrieved from the national scientific information systems developed by the National Research Council (Conselho Nacional de Desenvolvimento Científico e Tecnológico; CNPq) Lattes Platform, Directory of Research Groups in Brazil, 2002: http:// lattes.cnpq.br/diretorio, accessed on 07/Oct/ 2005), more specifically the "research group directory". These systems are now the basis of ScienTI, a recently established international scientific network which covers all scientific fields. Since 2002, under international bilateral agreements, CNPq has transferred information technology to the National Science and Technology Councils of nine countries (Argentina, Chile, Colombia, Equator, Panama, Paraguay, Peru, Portugal, and Venezuela). More recently, Cuba, Mexico, and Uruguay have shown interest in joining Red ScienTI, the international scientific network, and CvLAC, the system for human resources in science and technology 12 .

Guimarães 13 analyzed the performance of medical and biomedical research in Brazil based on data from the Institute for Scientific Information (ISI). The growth of indexed Brazilian publications in all scientific fields was impres-

Figure 2

The national effort in health research. Groups and researchers with and without health research activities. Brazil, 2004.

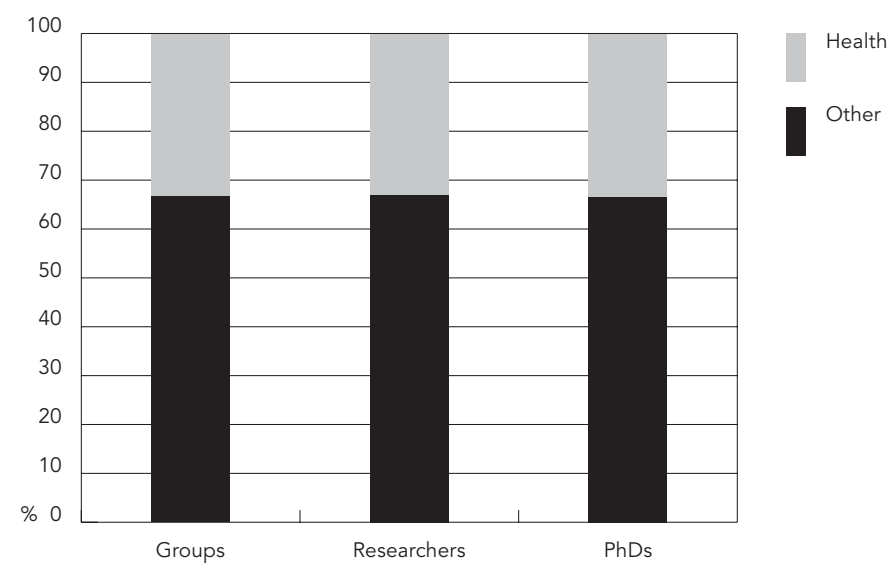

Source: Ministério da Saúde ${ }^{14}$. sive, increasing 165-fold from 1973 to 2001 (while during the same period global science output increased 2.18-fold), for a growth rate 76 times greater than the international scenario of scientific publications. In 1997-2001 Brazil occupied 23rd place among the 30 countries with the largest science output in the medical field and 21st in the biomedical field. Brazil was the only Latin American country represented in the former ranking and was followed by Mexico (29th) in the latter. Research interests and expertise cover a broad spectrum of disciplines and applications, from basic research to internal medicine and numerous others. However, in some crucial areas for the SUS, health research is incipient, notably in health technology assessment and health economics.

A preliminary estimate of funds invested in health research from 2000 to 2002 showed an annual mean of US\$573 million, as seen in Table 1 . The public sector accounted for $72.8 \%$, the private for-profit sector $23.7 \%$, and external funds $3.5 \% 14$. Until 2003 there was no national policy for science and technology in health, nor a priority agenda, so the choice of health research topics was left entirely to scientists. The Ministry of Health rarely influenced major decisions on health research investments.

\section{Proposing a policy for science, technology, and innovation in health}

The new Brazilian Administration which took office in January 2003 emphasized the central role of the national health authority (Ministry of Health) in structuring national health research efforts. It created the opportunity to draft a National Policy for Science, Technology, and Innovation in Health, which was approved during the 2nd National Conference on Science, Technology, and Innovation in Health held in July 2004, as described below in more detail.

That policy was based on two main principles, the first of which was the pursuit of health equity. Inequity is the Achilles' heel of Brazilian society. Regional indicators, as well as indicators referring to different social groups, show considerable social discrimination concerning health when patterns of morbidity, mortality, access to services, and quality in service procedures are examined. Increasing equity in the health system is the first principle of the $\mathrm{Na}$ tional Policy for Science, Technology, and Innovation in Health. Other authors have suggested that research should also increase equity in health outcomes between groups and 
within nations, because the knowledge generated can be utilized to improve the performance of the health system and, ultimately, health and health equity 2,15 . The foundations of an effective global health research endeavor should strengthen national health research capacities, together with the commitment to reduce inequalities both within and between countries 16 .

Commenting on the issue of priority setting, the World Health Organization (WHO) director for research policy and cooperation added another key principle: "health research should be based on sound ethical principles and avoid exploitation of vulnerable populations" 17 (p. 1399). There is no doubt that increasing restrictions and rising costs observed in the developed countries regarding experiments in anima nobile within their borders have stimulated the "exportation" of research projects, particularly clinical protocols and vaccine trials. Some of these protocols are expected to be applied in the populations of developing countries under circumstances that would be unacceptable in the country of origin. Strict adherence to ethical standards in health research is the second principle of the Brazilian policy.

A draft proposal for a National Policy for Science, Technology, and Innovation in Health was prepared by the National Health Council sub-committee on Science and Technology, including 56 items. The purpose was to have a backbone document to discuss during the 2nd National Conference on Science, Technology, and Innovation in Health. It was part of the Conference Manual, a document organized and published by DECIT/Ministry of Health 18.

\section{Establishing a Priority Agenda for Health Research}

The need to focus health research on high-priority problems at the national level has been pointed out in the international scenario over the past decade, as described previously. However, much has been said about the "need to", but not so much about "how to". The political process to guarantee an adequate and broad consensus is not an easy task, especially if one wants not only to involve small scientific committees, but also to extend the horizons to the community at large.

The establishment of a comprehensive agenda for health research priorities in Brazil began in June 2003, when the Ministry of Health appointed a Technical Advisory Committee, comprised of 20 distinguished scientists and health policymakers. This group, in consonance with
Table 1

Expenditures in health research in Brazil, 2000/2002, according to main sources of funding (US\$).

\begin{tabular}{lrr}
\hline Sources & $\mathbf{2 0 0 0 / 2 0 0 2}$ & Annual mean \\
\hline Federal government & $680,449,513$ & $226,816,504$ \\
$\quad$ Ministry of Health & $97,907,787$ & $32,635,929$ \\
$\quad$ Ministry of Science and Technology & $153,165,909$ & $51,055,303$ \\
$\quad$ Ministry of Education & $429,375,817$ & $143,125,272$ \\
State governments & $571,479,120$ & $190,493,040$ \\
$\quad$ State Secretaries of Education & $412,450,191$ & $137,483,397$ \\
$\quad$ and Science & & \\
$\quad$ State Agencies for the Development & $159,028,929$ & $53,009,643$ \\
$\quad$ of Science & & \\
Public sector & $1,251,928,633$ & $417,309,544$ \\
Private sector & $406,928,244$ & $135,642,748$ \\
International agencies and organizations & $60,468,724$ & $20,156,241$ \\
Total & $1,719,325,601$ & $573,108,534$
\end{tabular}

Source: Ministério da Saúde 14

the National Health Council sub-committee on Science and Technology, proposed 21 sub-agendas to address the specificities and breadth of the health research area, listed in Table 2 (subagendas highlighted in Table 2 were incorporated afterwards, during the 2nd National Conference on Science, Technology, and Innovation in Health).

The next step was to identify research priorities for each sub-agenda, which began during a national seminar on November 6-7, 2003, convening 408 professionals, especially health researchers $(68 \%)$, health policymakers, and healthcare providers (32\%). Separate seminars were held previously to set research priorities on two subjects: "Dengue Fever" and "Violence, Accidents, and Trauma”, with participation by 102 professionals, because these calls for proposals were planned for 2003. Therefore, the final number of specialists and policymakers involved in the entire process was 510 . The range of experts involved biomedical, clinical, and public health researchers as well as health policymakers and healthcare providers at the municipal, State, and Federal levels.

The choice of participants guaranteed that all relevant actors and stakeholders were adequately represented. Regarding invited researchers, criteria were experience and publications in the field, as well as a leading position in the national scientific scenario. The choice was based on data retrieved from the national scientific information systems of CNPq, as already mentioned. Healthcare providers and 
National agenda for health research priorities. Brazil, 2004

Research sub-agendas approved by the 2nd National Conference on Science, Technology, and Innovation in Health

01. Indigenous peoples' health

02. Mental health

03. Violence, accidents, and trauma

04. Health of African descendents*

05. Chronic diseases

06. Health of the elderly

07. Child and adolescent health

08. Women's health

09. Health of people with disabilities*

10. Food and nutrition

11. Bioethics and ethics in research

12. Clinical research
13. Health industrial complex (equipment, vaccines, drugs, diagnostic devices)

14. Health technology assessment / Health economics

15. Epidemiology

16. Demography in health

17. Oral health*

18. Health promotion (risk factors)

19. Infectious and parasitic diseases

20. Communication \& information in health

21. Work in health and health education

22. Health systems and policies

23. Health, environment, labor, and bio-safety

24. Pharmaceutical assistance

* Sub-agendas highlighted were incorporated during the 2nd National Conference on Science, Technology, and Innovation in Health.

policymakers were chosen at all three levels (Federal, State and municipal), considering their contribution and experience in the specific area of a particular sub-agenda.

For both types of participants, the final choices were guided by a strong concern to guarantee a fair distribution as far as gender and State of origin, so that the country's five regions and most of the States were represented. The largest number of participants was from Brasília, the national capital, where the Ministry of Health has its headquarters, followed by Rio de Janeiro, home to the Oswaldo Cruz Foundation (Fundação Oswaldo Cruz - FIOCRUZ), the largest Brazilian Ministry of Health research institute.

Meetings were organized in groups of 15-25 individuals per sub-agenda with coordinators and rapporteurs appointed by the DECIT. Logistic support was provided to make the process of drafting proposals as interactive as possible. At the end of the two-day meeting, proposals were immediately made public to all participants. For each of the 20 sub-agendas, some 15 to 40 priority topics were proposed.

After minor editorial changes, the agenda was submitted to a formal public consultation on the Ministry of Health website for 45 days, aiming to expand the consultation and reach health professionals and the community at large 19. During this period 1,900 individuals registered online to access the document. A total of 360 comments and contributions were received, analyzed, published, and made available to be discussed during the Conference. All versions of these documents were saved for further consultation.

\section{Second National Conference on Science, Technology, and Innovation in Health}

Historical background: the 1 st National Conference on Science and Technology in Health was held in 1994, and although it represented a breakthrough, its organization did not allow ample participation. However, some of the proposals set forth during the Conference, like the creation of a Science and Technology Secretariat, were implemented by the new Brazilian Administration in early 2003.

Political aspects: the 2nd National Conference on Science, Technology, and Innovation in Health, held on July 25-28, 2004, was an initiative by three Ministries: Health, Education, and Science and Technology. During the preparatory phase, lasting some three and a half months, 307 cities and 24 States (out of 27) organized their local conferences, involving some 15,000 participants. Three hundred and sixty health sector delegates were appointed by the local conferences for the national phase. In addition, 120 delegates were named by the education sector and 120 by the science and technology sector. There were 644 participants, most of whom were health researchers, coordinators of graduate courses, university hospital managers, representatives of the main scientific societies, etc. Figure 3 shows the distribution of participants. The Minister of Health and numerous other high-level government officials were present to open the Conference plenary session.

Logistics: as usual in Brazilian health conferences, State Health Councils organized local conferences and meetings, usually extending 
Distribution of participants in the 2nd National Conference on Science, Technology, and Innovation in Health, according to categories represented. Brazil 2004.

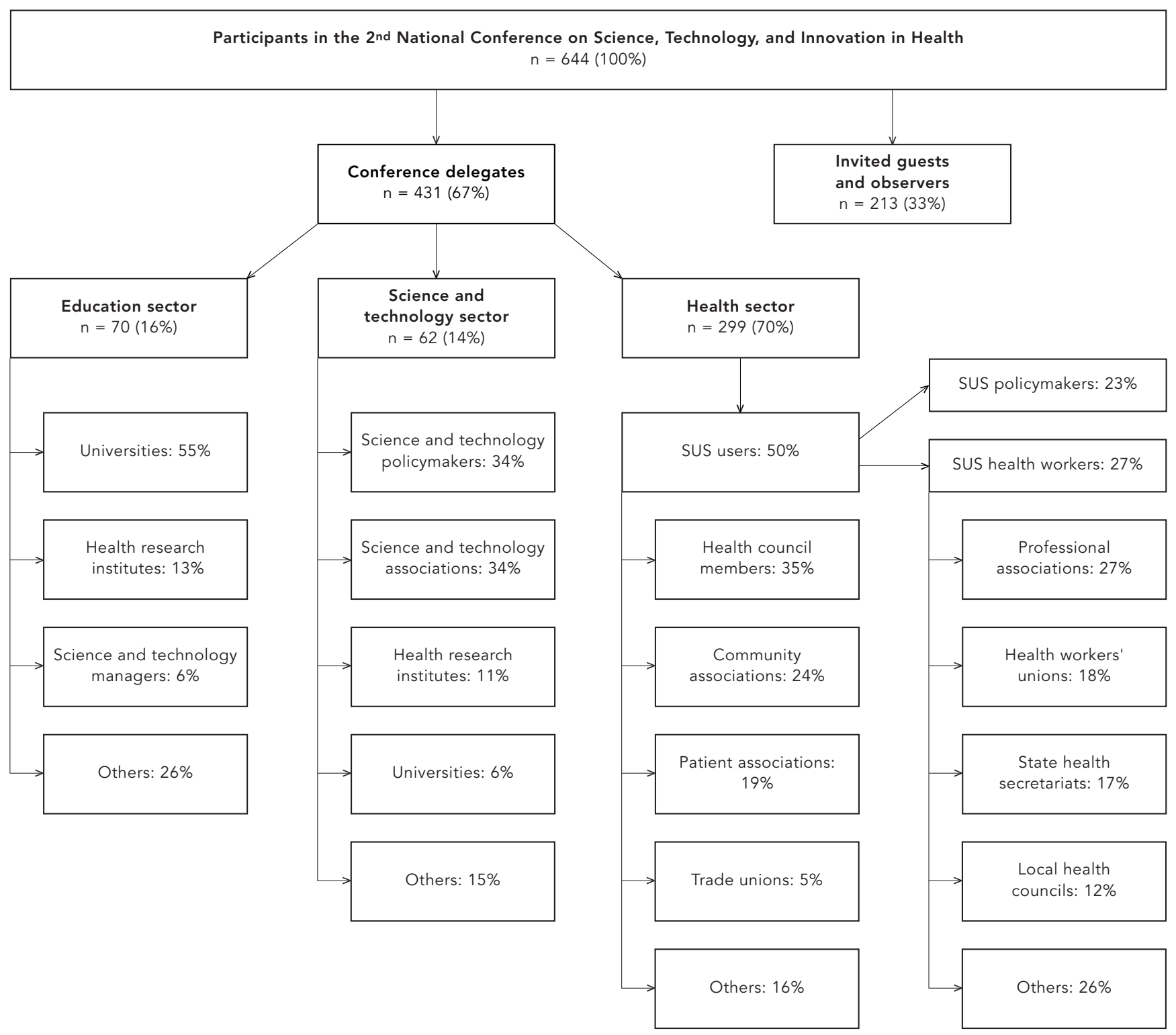

through the weekend in order to maximize the opportunity for community participation. In all cases, the proportionality of $50 \%$ clientele (community representatives of SUS users), 25\% health managers/healthcare providers, and $25 \%$ health workers, was strictly adhered to. Delegates elected to represent each State in the National Conference respected this proportionality, which is a standard procedure in Brazil- ian health conferences. The States provided transportation (ground or air, as needed) to allow participation by their delegations. The Ministry of Health provided meeting rooms, accommodations for community representatives, and meals and local transportation for all participants. This is normal procedure in Brazilian health conferences, and the purpose of the government's contribution is to allow partici- 
pation by community representatives, who would otherwise be unable to come to Brasília. Community leaders do not interpret this support as a potential conflict of interest; they are absolutely free to exercise their citizens' rights, and they openly and heavily criticize the health policies with which they disagree.

Methodological aspects: the two main themes of the conference were: (a) the National Policy for Science, Technology, and Innovation in Health and (b) the Priority Agenda for Health Research. The local, regional, and State conferences discussed the Conference Manual in depth 18. This publication was organized and published by DECIT/Ministry of Health on behalf of the National Health Council sub-committee on Science and Technology. It included 56 items describing the proposal for a National Policy for Science, Technology, and Innovation in Health, and also the Priority Agenda for Health Research, drafted as described previously and comprising $20 \mathrm{sub}$ agendas. The process of local/municipal/State conferences resulted in 24 documents emerging from each of the States. During the week before the conference, a group of 31 high-level rapporteurs (health professionals, including scientists) was convened to consolidate the final document, to be discussed and approved during the National Conference. This process was facilitated by software developed by the SUS Department of Data and Information Technology (Departamento de Informação e Informática do SUS - DATASUS). The tool allowed editing, additions, and suppressions to the text, keeping track of the original text and (very importantly) the names and States of the delegates proposing the changes. Color codes were generated automatically for amendments, suppressions, and substitutions as rapporteurs entered the modifications. As the Conference proceeded, the consolidated document was displayed on giant screens in the meeting rooms, so delegates could follow the proposed changes as they were included. All versions of the above documents were saved for further consultation. Our effort was to overcome the problem observed in most countries: not fully documenting the crucial intervening steps leading to the selection of research priority areas and topics, thus causing problems of reliability and credibility 7 .

Summary of conference debates: during the Conference, both the policy document and agenda were discussed and voted point by point, preceded by a broad debate. After three days of intense discussions, explanations, and deliberations, the policy document was approved 20 . The original policy document was expanded from 56 to 79 items after incorporat- ing the proposals approved during the Conference. The only really contentious point in the policy document was the proposal to create a health research support agency. Most scientists and many policymakers agreed to the proposal, while community representatives strongly opposed it. This was the only point which put "science" on one side and the "community" on the other. The concern that the National Health Council could "lose control" of research funds was expressed by the opponents; the proposal was finally voted and rejected. As a result of this intense participatory process, many research topics were added to the agenda and three other sub-agendas emerged, with their corresponding detailed research topics: (a) Oral Health; (b) Health of African Descendents; and (c) Health of People with Disabilities, as shown in Table 3 . Not all topics proposed by patients' groups were approved, especially those regarding rare diseases. The Conference was a challenge for both scientists and community leaders. Never before had these social actors made such an effort to speak a common language, to interact in such depth, and to openly discuss their sometimes conflicting points of view.

\section{Implementing the health research policy and agenda}

The health research policy and agenda are currently orienting the allocation of Ministry of Health funds for scientific research and development. As stated previously, implementing these into programs and projects has been the main goal since the beginning. In the period 2003-2005, the DECIT/Ministry of Health launched several calls for proposals, as shown in Table 3.

In 2003, before the policy and agenda were approved, there were some investments to support research projects on pressing issues. The DECIT/Ministry of Health financed projects for the National Research Taskforce on Dengue Fever and nine projects for the Brazilian Tuberculosis Network, as well as 148 small operational research projects for the SUS (Table 3). Research investment in the Dengue Fever Taskforce was shared with the Ministry of Science and Technology.

Many of the subsequent calls for proposals (2004-2005) were run jointly by DECIT/Ministry of Health and the Ministry of Science and Technology; one (01. Indigenous Peoples' Health) was funded by DECIT/Ministry of Health and the National Health Foundation (Fundação Na- 
Calls for Proposals launched by the Science and Technology Department (DECIT),

Ministry of Health. Brazil, 2003-2005*

\begin{tabular}{|c|c|c|c|}
\hline \multirow[t]{2}{*}{ Year } & \multirow[t]{2}{*}{ Research sub-agenda/Research call for proposals } & \multicolumn{2}{|c|}{ Projects } \\
\hline & & Received & Approved \\
\hline \multirow[t]{5}{*}{2003} & 19. Tuberculosis Research Network & 9 & 9 \\
\hline & 19. National Research Taskforce in Dengue** & 116 & 39 \\
\hline & 22. Operational research for SUS (State-level grant applications) & 383 & 148 \\
\hline & 11. Support to local research ethics committees & 103 & 64 \\
\hline & Total for 2003 & 611 & 260 \\
\hline \multirow[t]{10}{*}{2004} & 03. Violence, accidents, and trauma** & 238 & 61 \\
\hline & 10. Nutrition and Food Security** & 462 & 85 \\
\hline & 08/07. Maternal and neonatal mortality & 131 & 41 \\
\hline & 17. Oral health & 220 & 28 \\
\hline & 19. Hantavirus and other RNA encapsulated viruses** & 40 & 29 \\
\hline & 22. Health systems and policies: quality and humanization & 162 & 45 \\
\hline & 12. Multi-center phase III trial on the use of adult autologous stem cells in cardiology** & 8 & 4 \\
\hline & 11. Support to local research ethics committees & 120 & 109 \\
\hline & 22. Operational research for SUS (State-level grant applications) ${ }^{\star \star \star}$ & 1,112 & 419 \\
\hline & Total for 2004 & 2,493 & 821 \\
\hline \multirow[t]{12}{*}{2005} & 12. Health bioproducts with therapeutic uses** & 21 & 8 \\
\hline & 12. Network of Clinical Research Centers** & 52 & 14 \\
\hline & 12. Stem cell therapy - innovative uses ${ }^{\star \star}$ & 106 & 41 \\
\hline & 14. Health economics and cost evaluation & 76 & 26 \\
\hline & 19. Leprosy & 68 & 33 \\
\hline & 05. Cancer research** & 243 & 36 \\
\hline & 02. Mental health** & 146 & 21 \\
\hline & 01. Indigenous peoples' health\# & 61 & 24 \\
\hline & 23. Health for the Amazon region & 49 & 15 \\
\hline & 12. Network for the evaluation of orthopedic materials**,\#\# & 32 & \\
\hline & 16. National Demographic and Health Survey\#\#\# & 4 & 1 \\
\hline & Total for $2005^{\star}$ & 858 & 219 \\
\hline \multicolumn{2}{|c|}{ Total for the period $(2003 / 2005)$} & 3,962 & 1,300 \\
\hline
\end{tabular}

* January through October 2005;

** Joint financial disbursements by Department of Science and Technology/Ministry of Health and Ministry of Science and Technology;

*** Joint financial disbursements by Department of Science and Technology/Ministry of Health and State agencies for research support:

\# Joint financial disbursements by Department of Science and Technology/Ministry of Health and National Health Foundation;

\#\# Undergoing peer review;

\#\#\# Joint financial disbursements by Department of Science and Technology/Ministry of Health and the Nutrition Division/Ministry of Health.

cional de Saúde - FUNASA), the institution responsible for indigenous peoples' health, and another large project (16. National Demographic and Health Survey) was financed by DECIT/ Ministry of Health and the Nutrition Division/ Ministry of Health. Most sub-agendas were contemplated, but some general ones like 15 . Epidemiology, 18. Health Promotion, and 21. Health Education were contemplated in most calls for proposals, as the specific themes included topics addressing these issues.

Our concern with ethics in research was clearly expressed in these public calls for proposals. Two of them were specially designed for institutional support to local ethics committees, and financial support reached 180 of the existing 350 committees. This program is run in close cooperation with the National Research 
Ethics Committee (Comissão Nacional de Ética em Pesquisa - CONEP) of the National Health Council.

Another large program, called Operational Research for SUS, was developed in partnership with all 27 State health departments and State research support agencies. Funds were decentralized to State agencies, which in turn disbursed a complement (from $10 \%$ to $100 \%$ of the Ministry of Health funds) and conducted State-level calls for proposals. These calls for proposals, already launched twice, have received a total of more than 1,000 research proposals (Table 3).

In 2004 the Ministry of Health also supported some projects from sub-agenda 13. Health Industrial Complex, including the development of some vaccines prioritized by the $\mathrm{Na}$ tional Immunization Program, diagnostic kits for TB and HCV, NAT tests for HIV, monoclonal antibodies related to blood transfusions, and clotting factors by recombinant technology. Also worthy of mention is the partnership with the Brazilian Cochrane Initiative in order to strengthen the evidence-based process of technological incorporation into the SUS.

In 2004, a budget of some US $\$ 25$ million was invested by DECIT to support health research and development. It was wholly disbursed, and an important point is the operational cost of running such a program. Out of the total budget, the amount spent directly to finance research corresponded to $97.6 \%$. The majority of the financial operations described above were performed with technical advice and operational cooperation from two Federal research- financing agencies, namely the CNPq and the National Agency for Technological Development (Financiadora de Estudos e Projetos - FINEP), both under the Ministry of Science and Technology.

During this period the DECIT/Ministry of Health relied on a staff of 34 to implement the agenda, hold the 2nd National Conference on Science, Technology and Innovation in Health, and implement research support (calls for proposals, direct contracts, etc). The group consisted primarily of professionals with graduate diplomas and experience in research (3 PhDs, 17 Masters, and 5 undergraduates), besides 2 public relations professionals and 7 administrative clerks. Personnel costs were not included in the above-mentioned budget figures for the Department.

\section{Conclusions}

The four main functions utilizing knowledge to improve health and health equity are stewardship, financing, creating and sustaining resources, and producing and using research 15.

We have described how these objectives were accomplished in Brazil including strong social participation in the process to promote equity in the policy and agenda. Given adequate political and financial support, it was possible to accomplish this in a three-year period. A process was thus launched to resituate the Ministry of Health in Brazilian health research efforts. The remaining challenge is to make these initial steps permanent and sustainable.

\section{Resumo}

A necessidade de estabelecer uma política de ciência e tecnologia em saúde e prioridades de pesquisa em saúde foi destacada no cenário internacional. No Brasil, estes processos iniciaram em 2003, quando um grupo designado pelo Conselho Nacional de Saúde propôs 20 subagendas para abarcar as especificidades da pesquisa em saúde. O segundo passo foi identificar prioridades em cada subagenda, durante seminários nacionais envolvendo 510 cientistas e gestores. A $2 \underline{a}$ Conferência Nacional de Ciência, Tecnologia e Inovação em Saúde ocorreu em julho de 2004. Durante a fase preparatória 307 municípios e 24 Estados organizaram conferências locais, envolvendo 15 mil pessoas. Do setor saúde foram indicados 360 delegados nas conferências locais, além dos indicados pelos setores de educação e ciência e tecnologia. Durante a conferência, a política nacional foi aprovada e três novas subagendas foram introduzidas e aprovadas. Atualmente, a política nacional e a agenda de prioridades estão guiando os investimentos de recursos para pesquisa e desenvolvimento do Ministério da Saúde e, de certa forma, do Ministério da Ciência e Tecnologia. Entre 2003 e 2005, 24 editais de pesquisa foram lançados, nos quais foram recebidas 3.962 propostas de pesquisa e aprovadas 1.300 .

Pesquisa; Participação Comunitária; Política de Saúde 


\section{Contributors}

The four authors participated in all stages of the policy setting process and contributed to this article. R. Guimarães wrote a first draft of the manuscript and L. M. P. Santos was responsible for writing and revising the final version.

\section{Acknowledgments}

We wish to thank the Department of Science and Technology staff for their great dedication during the organization of the Agenda Seminars and the 2nd National Conference and also the 15,000 volunteers who participated in the local, State, and national conferences. We are also grateful to the staff of the National Research Council and National Agency for Technological Development for the intense and highly productive inter-institutional partnership developed during the implementation of the agenda. Finally, we should acknowledge the numerous Brazilian scientists and health managers who participated in defining the policy and agenda as well as those engaged in peer review to analyze the three thousand research projects generated during this process.

\section{References}

1. Annan K. Science for All Nations. Science 2004; 303:925.

2. Labonte R, Spiegel J. Setting global health research priorities. BMJ 2003; 326:722-3.

3. The Commission on Health Research for Development. Health research: essential link to equity in development. Oxford: Oxford University Press; 1990.

4. Task Force on Health Research for Development. Essential National Health Research: a strategy for action in health and human development. Geneva: Task Force on Health Research for Development; 1991.

5. Global Forum for Health Research. The 10:90 report on health research. http://www.globalforum health.org/site/002_What\%20we\%20do/005_Pub lications/001_10\%2090\%20reports.php (accessed on $07 /$ Oct/2005).

6. Council on Health Research for Development. Priority setting for health research: lessons from developing countries. The Working Group on Priority Setting. Health Policy Plan 2000; 15:130-6.

7. Kitua AY, Mashalla YJS, Shija JK. Coordinating health research to promote action: the Tanzanian experience. BMJ 2000; 321:821-3.

8. Paim JS. Atenção à saúde no Brasil. In: Guimarães R, Angulo-Tuesta A, organizadores. Saúde no Brasil; contribuições para a Agenda de Prioridades de Pesquisa. Brasília: Ministério da Saúde; 2004. p. 15-40.

9. Departamento de Informação e Informática do SUS, Ministério da Saúde. Sistema de Informações de Saúde. Assistência à saúde: internações hospitalares e produção ambulatorial. http:/ /www. datasus.gov.br (accessed on 07/Oct/2005).

10. Noronha JC, Lima LD, Machado CV. A gestão do Sistema Único de Saúde: características e tendências. In: Guimarães R, Angulo-Tuesta A, organizadores. Saúde no Brasil: contribuições para a Agenda de Prioridades de Pesquisa. Brasília: Ministério da Saúde; 2004. p. 41-86.
11. Conselho Nacional de Saúde. Emenda Constitucional n. 29: um avanço significativo para o setor saúde. http://conselho.saude.gov.br/ultimas_ noticias/2005/ec29.htm (accessed on 07/Oct/2005).

12. de los Rios R, Santana PHA. El espacio virtual de intercambio de información sobre recursos humanos en Ciencia y Tecnología de América Latina y el Caribe Del CV Lattes al CvLAC. Ci Inf 2001; 30:42-7.

13. Guimarães JA. A pesquisa médica e biomédica no Brasil: comparações com o desempenho científico brasileiro e mundial. Ciênc Saúde Coletiva 2004; 9:303-27.

14. Ministério da Saúde. Fluxos de recursos em P\&D em saúde no Brasil. Rio de Janeiro: Departamento de Ciência e Tecnologia; 2004. (Relatório de Pesquisa, 2).

15. Pang T, Sadana R, Hanney S, Bhutta ZA, Hyder AA, Simon J. Knowledge for better health: a conceptual framework and foundation for health research systems. Bull World Health Organ 2003; 81:815-20.

16. Sadana R, Pang T. Health research systems: a framework for the future. Bull World Health Organ 2003; 81:159.

17. Pang T. Setting global health research priorities: ethics should also guide global health research. BMJ 2003; 326:1399.

18. Conselho Nacional de Saúde, Ministério da Saúde. Manual da 2ạ Conferência Nacional de Ciência, Tecnologia e Inovação em Saúde. http://dtr 2001.saude.gov.br/sctie/2cnctis.htm (accessed on $07 /$ Oct/2005).

19. Departamento de Ciência e Tecnologia, Ministério da Saúde. Agenda nacional de prioridades de pesquisa em saúde. http://dtr2001.saude.gov.br/ sctie/2cnctis.htm (accessed on 07/Oct/2005).

20. Departamento de Ciência e Tecnologia, Ministério da Saúde. Anais da 2a Conferência Nacional de Ciência, Tecnologia e Inovação em Saúde. http:// dtr2001.saude.gov.br/sctie/2cnctis.htm (accessed on $07 /$ Oct/2005).

Submitted on $07 /$ Nov/2005

Approved on 19/Dec/2005 